\title{
Iron and Nitrogen Containing Carbon Catalysts with Enhanced Activity for Oxygen Reduction in Proton Exchange Membrane Fuel Cells
}

\author{
Chitturi Venkateswara Rao ${ }^{1, *}$, Lingam Hima Kumar ${ }^{1}$, Balasubramanian Viswanathan ${ }^{1, *}$ \\ ${ }^{1}$ National Centre for Catalysis Research, Department of Chemistry, Indian Institute \\ of Technology Madras, Chennai 600036, India \\ E-mail:vrao.chitturi@ymail.com; bvnathan@iitm.ac.in
}

Received April 11 ${ }^{\text {th }}, 2011$; revised April 21 ${ }^{\text {st }}, 2011$; accepted May 12 ${ }^{\text {th }}, 2011$.

\begin{abstract}
Iron and nitrogen containing carbon catalysts were prepared by the pyrolysis of iron(III)tetramethoxyphenylporphyrin complex adsorbed on as-received as well as nitric acid treated carbon black and employed them as oxygen reduction electrodes for hydrogen-oxygen PEM fuel cells. The influence of carbon surface functional groups on the dispersion of active species and electrocatalytic performance is investigated using electron microscopic and electrochemical techniques. The existence of quinone functional groups on the nitric acid treated carbon was evident from X-ray photoelectron spectroscopy and cyclic voltammetry. Rotating disk electrode voltammetry results affirmed the good electrocatalytic activity and stability of pyrolyzed macrocyclic complex adsorbed on nitric acid treated carbon compared to that of as-received carbon. This is ascribed to the greater number of $\mathrm{Fe} / \mathrm{N}$ active species as well as good dispersion of metal clusters over nitric acid treated carbon support. Fuel cell tests depicted the comparable performance of pyrolyzed complex adsorbed on nitric acid treated carbon with commercial Pt/C at $353 \mathrm{~K}$. Durability measurements performed under fuel cell operating conditions for $120 \mathrm{~h}$ indicate the good stability of the catalysts.
\end{abstract}

Keywords: Iron-based Clusters, Non-Precious Catalysts, Oxygen Reduction, PEM Fuel Cells

\section{Introduction}

Proton exchange membrane fuel cells (PEMFCs) appear to be one of the alternate energy sources [1]. Carbon supported platinum is the active, efficient and applicable catalyst for hydrogen oxidation and oxygen reduction in PEMFCs [1-5]. However, the usage of high amount of Pt for oxygen reduction reaction (ORR) at cathode increases the cost of the device and hinders commercialization. Also, Pt electrocatalysts has several drawbacks such as high overpotential $(\geq 300 \mathrm{mV})$ and sluggish kinetics for ORR beside the cost issue [5]. In recent years, there have been efforts to find suitable non-Pt based catalysts which exhibit the similar activity of Pt [6-10]. Transition metal (especially iron or cobalt), nitrogen and carbon containing catalysts in the form of $\mathrm{MN}_{\mathrm{x}} \mathrm{C}_{\mathrm{y}}$ appear to be one of the choices for ORR $[9,10]$.

Electrocatalysis of the ORR on transition metal macrocycle, cobalt(II)phthalocyanine ( $\mathrm{CoPc}$ ) adsorbed on carbon was reported for the first time by Jasinski [11]. There- after, several macrocyclic complexes were investigated as oxygen reduction electrodes for electrochemical devices [12-14]. All experimental evidences accumulated over the years have demonstrated that macrocyclic complexes of $\mathrm{Fe}$ and $\mathrm{Co}$ appear to be the best. However, they suffer from low electrochemical stability and decompose either via hydrolysis in the electrolyte or destruction of the macrocycle ring by peroxy intermediates generated during oxygen reduction [15]. The results were not satisfactory in terms of both the activity and stability of these $\mathrm{Co}$ and $\mathrm{Fe}$ chelates. Later several research groups reported that the heat-treatment of iron or cobalt macrocycles adsorbed on carbon support improves their activity and stability [15-22]. Moreover, a variety of methods have been employed to prepare electrocatalysts containing iron or cobalt, nitrogen and carbon and exploited them as ORR electrodes [23-25]. It was concluded that the activity depends on the metal, the ligand and nature of support. Efforts have been devoted to determine the composition and the structure of the active sites formed upon pyrolysis. The most 
widely accepted model to explain the improvement in activity and stability is the formation of $M-N_{x}$ moiety on carbon matrix or simply $\mathrm{MN}_{\mathrm{x}} \mathrm{C}_{\mathrm{y}}$ clusters $(\mathrm{M}=\mathrm{Fe}$ or $\mathrm{Co})$ during the pyrolysis [10, 6-32].

Activated carbon materials characterized by good surface area, tunable porosity, and high electronic conductivity were known to influence the catalytic activity thereby device performance. Numerous studies were reported on the preparation of activated carbon materials and their influence on the catalytic activity [33-35]. The methods were mainly concentrated on the treatment of carbon with a variety of chemical oxidants like $\mathrm{HNO}_{3}$, $\mathrm{H}_{2} \mathrm{O}_{2}$, hypochlorite etc. or gaseous molecules like $\mathrm{O}_{2}$, $\mathrm{NH}_{3}$, etc. The main purpose of the treatment was to create surface oxygen functionalities or to generate heteroatom-containing carbon nanostructures which were known to act as active sites for various processes/reactions [35-37]. Of the various approaches, treatment of carbon black with $\mathrm{HNO}_{3}$ was known to increase its hydrophilicity thereby increase the dispersion of metal/ metal complexes and enhances the performance of supported catalysts. In recent years, the effect of $\mathrm{HNO}_{3}$ treatment on the properties and performance of supported catalysts towards various industrially important reactions, namely, the chemical reduction of $\mathrm{NO}$ with $\mathrm{NH}_{3}$ [38], electrocatalytic oxidation of small organic molecules such as $\mathrm{H}_{2}$ [39], $\mathrm{CO}[39,40]$ and $\mathrm{CH}_{3} \mathrm{OH}$ $[41,42]$ and electrocatalytic reduction of air $[43,44]$ and oxygen [45-52] were investigated. The results insisted the enhanced activity and stability for the $\mathrm{HNO}_{3}$ treated carbon-supported catalysts. The enhanced performance was attributed to the increase in the surface area, high hydrophilicity, high degree of dispersion of active species, increase in the interaction between metal particle and support, and synergistic effect between the metal and oxygenated groups.

The objective of this work is to increase the number of $\mathrm{Fe} / \mathrm{N}$ active species at the surface, utilizing $\mathrm{N}_{4}-\mathrm{Fe}$ chelate (FeTMPP) and oxidized carbon black support, and compare their ORR activity and PEMFC performance with commercial $\mathrm{Pt} / \mathrm{C}$.

\section{Experimental Section}

\subsection{Materials}

All the chemicals used were of analytical grade. Pyrrole, p-anisaldehyde, propionic acid, N,N'-dimethylformamide, chloroform, benzene, acetone, iron (II) acetate and concentrated nitric acid (70\%) were obtained from Merck. Millipore-Q water (Merck) was used throughout the work. Commercial $\mathrm{Pt} / \mathrm{C}$ was procured from E-TEK. Carbon black (CDX975) received from Columbian Chemicals Company, USA was used as support.

\subsection{Modification of Carbon Black Support}

The as-received carbon was treated with nitric acid to increase the surface quinone/hydroquinone groups which were known to increase the dispersion of metal complexes. In a typical procedure, $0.5 \mathrm{~g}$ of carbon black was treated with $20 \mathrm{ml}$ of concentrated $\mathrm{HNO}_{3}$. The suspension was refluxed for $7 \mathrm{~h}$ and cooled. Then it was filtered, washed with de-ionized water and methanol, and dried in an oven at $348 \mathrm{~K}$. For convenience, as-received and oxidized carbon black were designated as $\mathrm{C} 1$ and $\mathrm{C} 2$ respectively in the text.

\subsection{Preparation of $\mathrm{Fe}-\mathrm{N} / \mathrm{C}$ Catalysts}

Iron-tetramethoxyphenylporphyrin (FeTMPP) complex was synthesized according to the method described by Adler et al. [53]. Elemental composition (wt.\%) of the purified FeTMPP complex was found as C, 66.81; H, 4.07; N, 6.43 and Fe, 6.57. It was in good agreement with calculated values $(\mathrm{C}, 66.95 ; \mathrm{H}, 4.18 ; \mathrm{N}, 6.51$ and $\mathrm{Fe}$, 6.49). The synthesized FeTMPP complex was adsorbed on $\mathrm{C} 1$ and $\mathrm{C} 2$ carbon blacks by dissolving the suitable amount of FeTMPP in chloroform followed by impregnation. Then the resultant suspension was filtered, washed with distilled water and dried at $348 \mathrm{~K}$. Finally it was ground into fine powder and heat-treated at $1073 \mathrm{~K}$ for $2 \mathrm{~h}$ under Ar atmosphere to generate Fe-N/C catalyst. The catalysts were prepared in such a way that it contain approximately 2 wt.\% Fe. The heat- treated FeTMPP adsorbed on $\mathrm{C} 1$ and $\mathrm{C} 2$ were designated as $\mathrm{C} 1-\mathrm{FeTMPP}$ (HT) and C2-FeTMPP (HT), respectively.

\subsection{Characterization Techniques}

The chemical compositions of the materials were determined by Hereaus CHN analyzer. Scanning electron microscope with EDX (FEI, Model: Quanta 200) was used to observe the surface morphology and composition of the catalysts. Surface area and pore size distribution of carbon black were investigated by Brunauer-EmmettTeller (BET) analyses with nitrogen adsorption-desorption isotherms on a Carlo-Erba sorptometer (Model 1800) instrument at $77 \mathrm{~K}$. X-ray photoelectron spectroscopy (XPS) measurements were carried out with Omicron nanotechnology instrument using an $\mathrm{Mg}$ monochromatic $\mathrm{X}$-ray $(\mathrm{h} v=1253.6 \mathrm{eV})$ at a power of $350 \mathrm{~W}$ operated under the base pressure of $\leq 2 \times 10^{-9}$ mbar. Particle size was determined using transmission electron microscope (TEM, JEOL2100). An inductively coupled plasma optical emission spectroscopic (ICP-OES) technique was employed to determine metal content in the catalysts. Powder XRD patterns were obtained on a Siemens 
D5000 diffractometer operating with the $\mathrm{Cu} \mathrm{K \alpha}$ radiation $(\lambda=1.5408 \AA$ ) generated at $40 \mathrm{kV}$ and $30 \mathrm{~mA}$.

\subsection{Electrochemical Measurements and Single-Cell PEMFC Tests}

ORR measurements were performed at room temperature by rotating disk electrode (RDE) voltammetry using a potentiostat (BAS 100 electrochemical analyzer) connected to a three electrode cell assembled with $\mathrm{RDE}$ glassy carbon disk as the working electrode, $\mathrm{Ag} / \mathrm{AgCl}(+$ $0.205 \mathrm{~V}$ vs NHE) as the reference and $\mathrm{Pt}$ foil as the counter electrodes, respectively. Oxygen saturated $0.5 \mathrm{M}$ $\mathrm{H}_{2} \mathrm{SO}_{4}$ was used as the electrolyte. The working electrode fabricated with $\mathrm{Fe}$-based catalysts was as follows $[19,20,29,30] .16 \mathrm{mg}$ of the catalyst, $0.4 \mathrm{ml}$ of $\mathrm{H}_{2} \mathrm{O}$ and $0.4 \mathrm{ml}$ of 5 wt.\% Nafion ${ }^{\circledR}$ (Aldrich) were ultrasonically blended for $10 \mathrm{~min}$. Then $10 \mu \mathrm{l}$ of this suspension was pipetted onto the glassy carbon disk and dried under $\mathrm{Ar}$ atmosphere. The working electrode, Pt/C (E-TEK) was fabricated to contain $14 \mu \mathrm{g}_{\mathrm{Pt}} / \mathrm{cm}^{2}$ according to our earlier report [2]. Current densities were normalized to the geometric area of the RDE disk $\left(0.283 \mathrm{~cm}^{2}\right)$.

Single-cell PEM tests were conducted using a homemade fuel cell test station. Gas diffusion electrodes (GDE) and membrane-electrode assembly (MEA) were fabricated according to the procedure reported in literature $[2,23,29]$. A commercial 20 wt.\% Pt/C (E-TEK) and the prepared Fe-based catalysts were used to fabricate anode and cathode, respectively. A homogeneous catalyst suspension consisting of $12.9 \mathrm{mg}$ of catalyst, $0.5 \mathrm{ml}$ of $\mathrm{H}_{2} \mathrm{O}$ and $0.3 \mathrm{ml}$ of 5 wt.\% Nafion solution was blended ultrasonically for $1 \mathrm{~h}$. This suspension was applied on the teflonized carbon cloth substrate by layer wise. Both anode and cathode electrodes were then placed in a vacuum oven at $348 \mathrm{~K}$ for $1 \mathrm{~h}$. The anode consists of $0.4 \mathrm{mg}_{\mathrm{Pt}} / \mathrm{cm}^{2}$. The cathode fabricated with Fe-based catalysts consists of $50 \mu \mathrm{g}_{\mathrm{Fe}} / \mathrm{cm}^{2}$. To compare the performance of Fe-based catalysts with Pt catalysts, cathodes containing 50 and $100 \mu \mathrm{g}_{\mathrm{Pt}} / \mathrm{cm}^{2}$ were fabricated using 20 wt.\% Pt/C (E-TEK). The single-cell membrane- electrode assembly (MEA) was fabricated by sandwiching the Nafion 115 membrane between the cathode and anode by hot pressing at $413 \mathrm{~K}$ and 50 $\mathrm{kg} / \mathrm{cm}^{2}$ for $1 \mathrm{~min}$. All fuel cell measurements were performed at $353 \mathrm{~K}$. Both $\mathrm{O}_{2}$ and $\mathrm{H}_{2}$ gas back pressures were set at 20 psi (1.38 bar). The two gases were humidified prior to admission into the fuel cell by passing them through stainless steel containers filled with $\mathrm{H}_{2} \mathrm{O}$ kept at $373 \mathrm{~K}$. Before the steady-state polarization curves were recorded, the cell was left under open circuit conditions for $30 \mathrm{~min}$ (MEA conditioning). A polarization curve was then recorded by varying the applied potential.

\section{Results and Discussion}

\subsection{Salient Features of Carbon Black Support (CDX975)}

The as-received carbon black (C1) was characterized by SEM, TEM and XRD. Specific surface area and pore size distribution were investigated by Brunauer-EmmettTeller (BET) analysis. SEM and TEM images of carbon black particles (CDX975) were shown in Figure 1. SEM images show that the carbon black was made of spherical aggregates about 150-200 nm in size (Figure 1a). TEM image reveal that each aggregate being made of elementary particles of about 50-80 nm (Figure 1b). Figure 1c represents the XRD pattern of carbon black particles. The carbon particles exhibited characteristic (002) and (101) diffraction peaks at $2 \theta$ values around 25 and $43^{\circ}$, respectively. The broad diffraction peak (002) with low intensity indicates the amorphous nature of carbon black. The BET specific surface area of the carbon sample is $260 \mathrm{~m}^{2} / \mathrm{g}$. The pore diameter distribution is shown in Figure 1d confirms the dominant pore diameter of the carbon particles is in the range of $2-50 \mathrm{~nm}$, which was in the mesopore range. In fact, mesopores with pore diameters of 2 - $50 \mathrm{~nm}$ were accessible to nitric acid oxidation since they possess a combination of high surface area and large pore diameter [54]. Also, mesoporous structure was a key factor contributing to the feasibility of carbon supports in electrocatalysis [55].

\subsection{XPS Analysis of $\mathrm{C} 1$ and $\mathrm{C} 2$ Carbon Blacks}

To gain more insight into the surface functionalities created by nitric acid treatment, XPS measurements were performed. XPS survey-scan spectra show $\mathrm{C} 1 \mathrm{~s}$ and $\mathrm{O} 1 \mathrm{~s}$ peaks at 284 and $532 \mathrm{eV}$ in the both as-received (C1) and nitric acid treated carbon (C2) samples. The observed $\mathrm{C} 1 \mathrm{~s}$ peak mainly represents amorphous carbon. The increase in the intensity of $\mathrm{O} 1 \mathrm{~s}$ peak from $\mathrm{C} 1$ to $\mathrm{C} 2$ indicates the presence of greater oxygen functionalities in the C2 sample. This is due to the nitric acid treatment. The assignment of peaks in the C1s spectra is in good agreement with literature reports [56,57]. The deconvoluted $\mathrm{XP} \mathrm{C} 1 \mathrm{~s}$ and $\mathrm{O} 1 \mathrm{~s}$ spectra of the $\mathrm{C} 1$ and $\mathrm{C} 2$ samples are shown in Figure 2. The predominant $\mathrm{C} 1$ s peak appears at $284.7 \pm 0.1 \mathrm{eV}$ for both $\mathrm{C} 1$ and $\mathrm{C} 2$ samples represent the amorphous nature of carbon. The peaks appeared at binding energies $284.3 \pm 0.1$ and $285.0 \pm 0.1 \mathrm{eV}$ are attributed to the $\mathrm{sp}^{2} \mathrm{C}$ and $\mathrm{sp}^{3} \mathrm{C}$, respectively. In the case of functionalized carbons, the additional peaks appeared at binding energies 286.1, 287.5, and $288.7 \mathrm{eV}$ are attributed to the $-\mathrm{C}-\mathrm{O}-,-\mathrm{C}=\mathrm{O}$, and $-\mathrm{O}-\mathrm{C}-\mathrm{O}-$, respectively. The absence of shake-up peak of carbon in $\mathrm{C} 1$ and $\mathrm{C} 2$ samples at $290.5 \mathrm{eV}\left(\pi-\pi^{*}\right.$ transition) indicates the amor- 
phous nature of carbon samples. The separation of $0.7 \pm$ $0.1 \mathrm{eV}$ between $\mathrm{sp}^{2}$ and $\mathrm{sp}^{3}$ peaks found for the amorphous $\mathrm{C} 1$ and $\mathrm{C} 2$ samples are in good agreement with the literature report [58]. It can be seen that the functional groups with either $\mathrm{C}-\mathrm{O}$ bonds or $\mathrm{C}=\mathrm{O}$ bonds are almost negligible on the as-received carbon $(\mathrm{C} 1)$ whereas the functional groups with both $\mathrm{C}-\mathrm{O}$ and $\mathrm{C}=\mathrm{O}$ bonds are found to be present on the oxidized carbon (C2).

The deconvoluted XP O1s spectra give two peaks for the $\mathrm{C} 1$ and $\mathrm{C} 2$ samples. The peaks at binding energies $531.6 \pm 0.1$ and $533.2 \pm 0.1 \mathrm{eV}$ are attributed to the oxygen doubly bonded to carbon in quinones, ketones, and aldehydes and oxygen singly bonded to carbon in ethers and phenols respectively. The intensities of both the $\mathrm{C}-\mathrm{O}$ and $\mathrm{C}=\mathrm{O}$ peaks increase after $\mathrm{HNO}_{3}$ treatment. The increase in surface concentration of oxygen from 1.3 to 7.8 at. $\%$ is observed.

\subsection{XPS Analysis of C1-FeTMPP(HT) and C2- FeTMPP(HT) Catalysts}

The studies performed on Fe-based non-precious ORR catalysts impart that the presence of $\mathrm{Fe} / \mathrm{N}$ species at the surface plays an important role in the adsorption and reduction of molecular oxygen [10,26,32,50-52]. To probe the nature of the species existed on the surface, XPS measurements were performed and the corresponding X-ray photoelectron (XP) narrow scan spectra are provided in Figure 3. Fe2p and N1s spectra are the average of 256 and 128 scans over the region of interest. As seen in the figure, both the catalysts have a component corresponding to iron and nitrogen species at the surface. The increase in the intensity of Fe2p and N1s peaks from C1-FeTMPP(HT) to C2-FeTMPP(HT) denote the presence of greater $\mathrm{Fe} / \mathrm{N}$ content at the surface of C2-FeTMPP(HT) catalyst. The Fe2 $\mathrm{p}_{3 / 2}$ narrow scan spectra shown in Figure 3(a) are characterized by a broad peak in the range of 705 and $711 \mathrm{eV}$ suggests the existence of iron in different oxidative states [59]. The vertical lines on the figure pinpoint the average binding energies of $\mathrm{Fe}^{2+}(707.1-708.7 \mathrm{eV}), \mathrm{Fe}^{0}$ (metallic iron/iron carbides, 706.7 - 707.2/706.7 - $706.9 \mathrm{eV})$, and $\mathrm{Fe}^{3+}(710.1$ - $711.2 \mathrm{eV})$. The XP N1s spectra of the catalysts shown in Figure 3(b) are characterized by two peaks and a tail at high energy. The vertical lines on the figure pinpoint the average binding energies of pyridinic (398.1-398.5 eV),

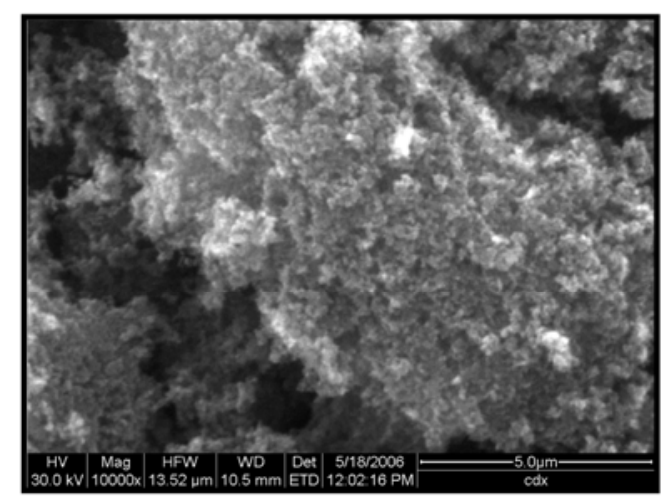

(a)

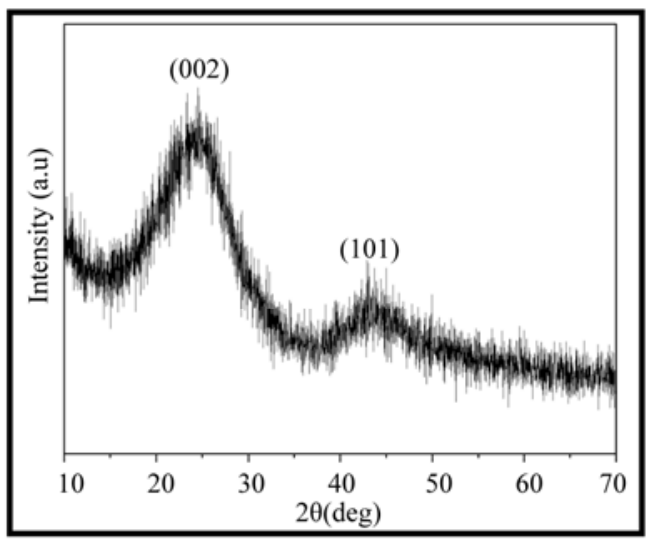

(c)

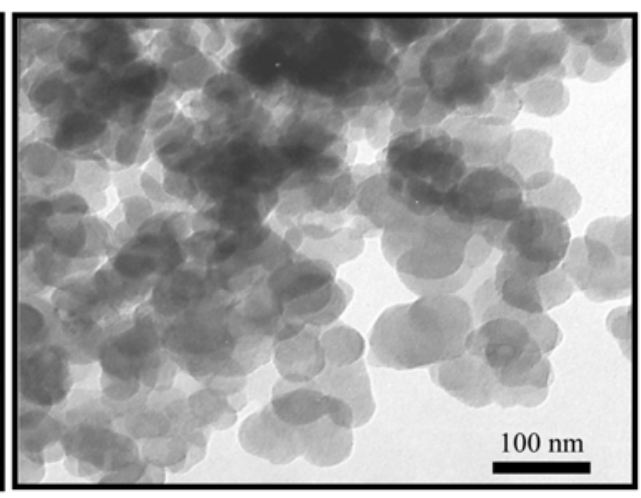

(b)

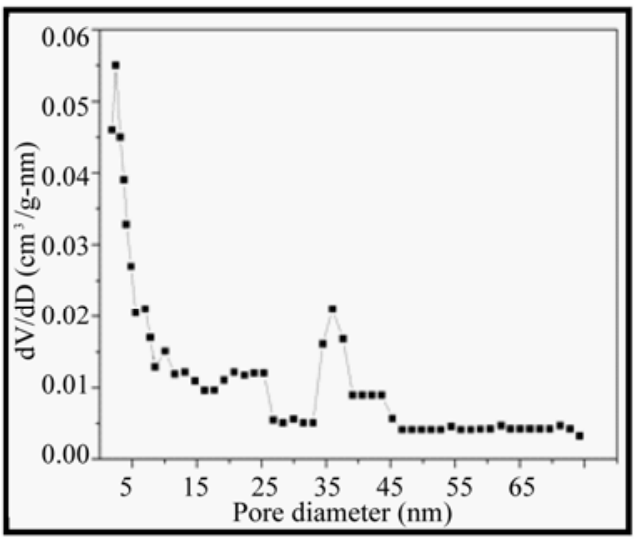

(d)

Figure 1. (a) SEM image; (b) TEM image; (c) XRD pattern; (d) pore size distribution of the as-received carbon black (C1). 


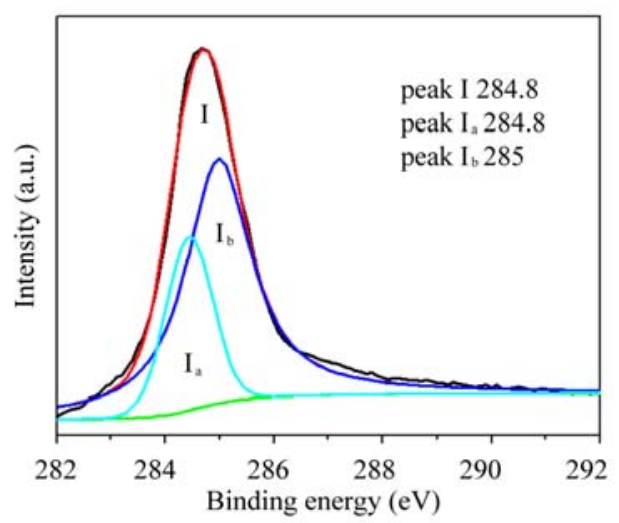

(a)

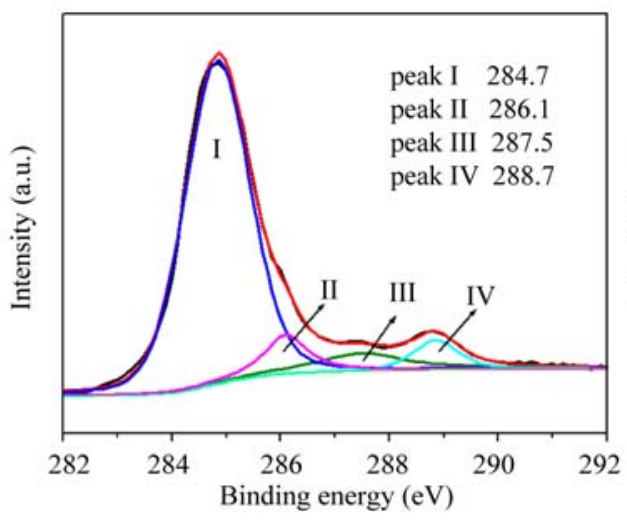

(c)

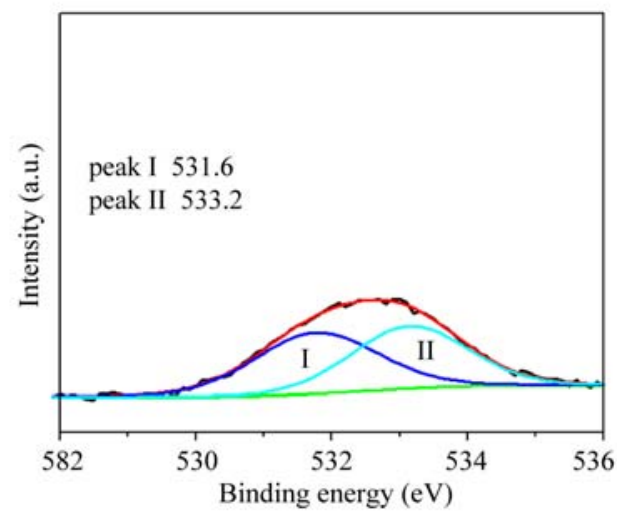

(b)

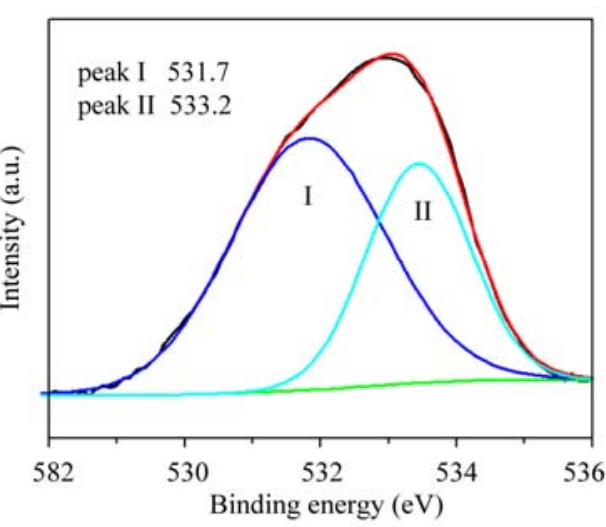

(d)

Figure 2. Deconvoluted XP C1s and O1s spectra of as-received carbon, C1 (a and b) and oxidized carbon, C2 (c and d).

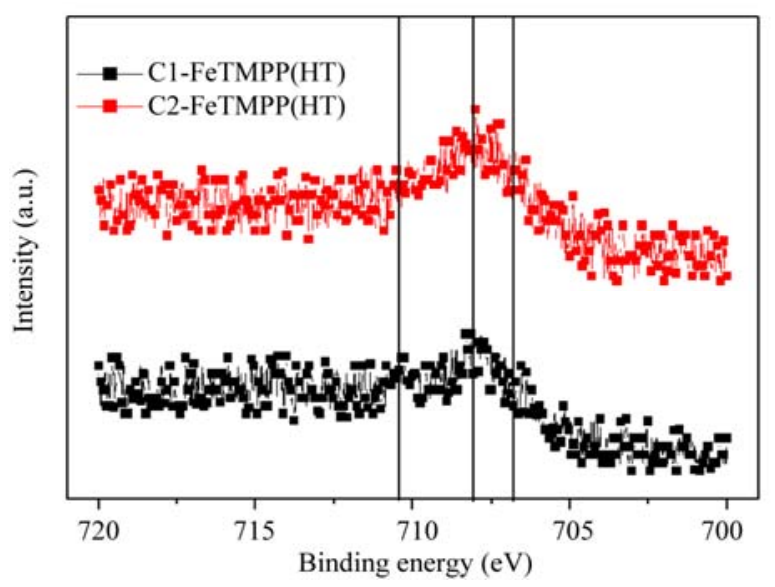

(a)

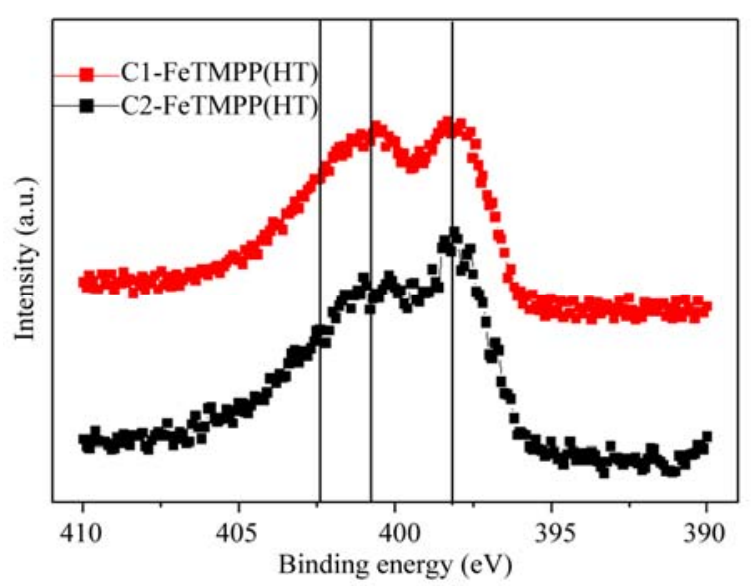

(b)

Figure 3. X-ray photoelectron spectra in (a) Fe2p and (b) N1s regions of the catalysts C1-FeTMPP (HT) and C2-FeTMPP (HT).

pyrrolic (399.8 - $401.3 \mathrm{eV})$, and quaternary (401.5 $403.1 \mathrm{eV}$ ) type nitrogen. Integration of the relative $\mathrm{Fe}$ and $\mathrm{N}$ elemental abundances indicates that the $\mathrm{C} 1$ -
FeTMPP(HT) catalyst contain $\sim 0.7$ at. $\%$ Fe and $\sim 2.2$ at. $\% \mathrm{~N}$ while C2-FeTMPP(HT) catalyst contain $\sim 1.3$ at. $\% \mathrm{Fe}$ and $\sim 3.4$ at. $\% \mathrm{~N}$ at the surface. 


\subsection{Electro-catalytic Performance of the Materials}

The as-received ( $\mathrm{C} 1)$ and oxidized (C2) carbon black supports were electrochemically analyzed to check the nature of the surface functional groups present. Cyclic voltammograms obtained for carbons $\mathrm{C} 1$ and $\mathrm{C} 2$ in deaerated $0.5 \mathrm{M} \mathrm{H}_{2} \mathrm{SO}_{4}$ was shown in Figure 4. A welldefined redox peaks at $\sim 0.55 \mathrm{~V}$ vs NHE was observed for $\mathrm{C} 2$. The observed redox peaks are corresponding to the presence of quinone/hydroquinone groups on the carbon surface $[48,60]$. These results are in good agreement with XPS results obtained for $\mathrm{C} 1$ and $\mathrm{C} 2$.

Linear sweep voltammograms (LSVs) recorded for the catalysts in $\mathrm{O}_{2}$-saturated $0.5 \mathrm{M} \mathrm{H}_{2} \mathrm{SO}_{4}$ at a scan rate of 5 $\mathrm{mV} / \mathrm{s}$ and rotation rate of $2500 \mathrm{rpm}$ are shown in Figure 5(a). For comparison, LSV recorded for $\mathrm{Pt} / \mathrm{C}$ is also shown. A single steep reduction wave with a well-developed limiting plateau similar to that of $\mathrm{Pt} / \mathrm{C}$ was observed for Fe-based catalysts. Voltammograms also depict the higher ORR activity and positive shift of ORR onset potential for C2-FeTMPP(HT) compared to C1FeTMPP(HT). The onset potential for ORR on C1FeTMPP(HT), C2-FeTMPP(HT) and Pt/C catalysts are $+840,+880$ and $+910 \mathrm{mV}$ vs NHE, respectively. It denotes that the over potential for ORR on C2- FeTMPP (HT) decreased by $40 \mathrm{mV}$ compared to C1-FeTMPP (HT). These results confirmed that the presence of oxygen functionalities (quinone groups) on carbon surface played an important role in formation and dispersion of $\mathrm{Fe} / \mathrm{N}$ active sites thereby enhanced ORR performance. Electrocatalytic ORR activity observed for the heattreated FeTMPP/C was due to the creation of $\mathrm{Fe} / \mathrm{N}$ moiety on carbon matrix during the pyrolysis $[29,30]$. Recently, we have demonstrated the necessity of $\mathrm{Fe}-\mathrm{N}_{4}$ clusters for the facile reduction of dioxygen molecule from density functional theory calculations [61]. In comparison with Pt/C, C2-FeTMPP(HT) catalysts exhibited high overpotential (ca. $30 \mathrm{mV}$ ) and also low ORR activity. Even though the ORR performance was inferior to that of $\mathrm{Pt} / \mathrm{C}$, still there is a possibility to improve the performance of carbon supported $\mathrm{Fe} / \mathrm{N}$ clusters by suitable electrode fabrication or by the modification of its electronic structure or by increasing the number of active sites through modified synthesis. Current density-time plots recorded for the electrodes in $\mathrm{O}_{2}$-saturated $0.5 \mathrm{M}$ $\mathrm{H}_{2} \mathrm{SO}_{4}$ at $0.7 \mathrm{~V}$ were shown in Figure 5(b). The performance of C2-FeTMPP(HT) was found to be better compared to C1-FeTMPP(HT). This may be due to the strong bonding interactions between the active species and oxidized carbon. Also, the performance was comparable with $\mathrm{Pt} / \mathrm{C}$.

The steep increase of ORR peak current observed for C2-FeTMPP(HT) compared to C1-FeTMPP(HT) may be due to the high surface area and distribution of active sites. BET surface area determined for the C1-FeTMPP (HT) and C2-FeTMPP(HT) catalysts was 57 and 103 $\mathrm{m}^{2} / \mathrm{g}$ respectively. In order to check the effect of surface

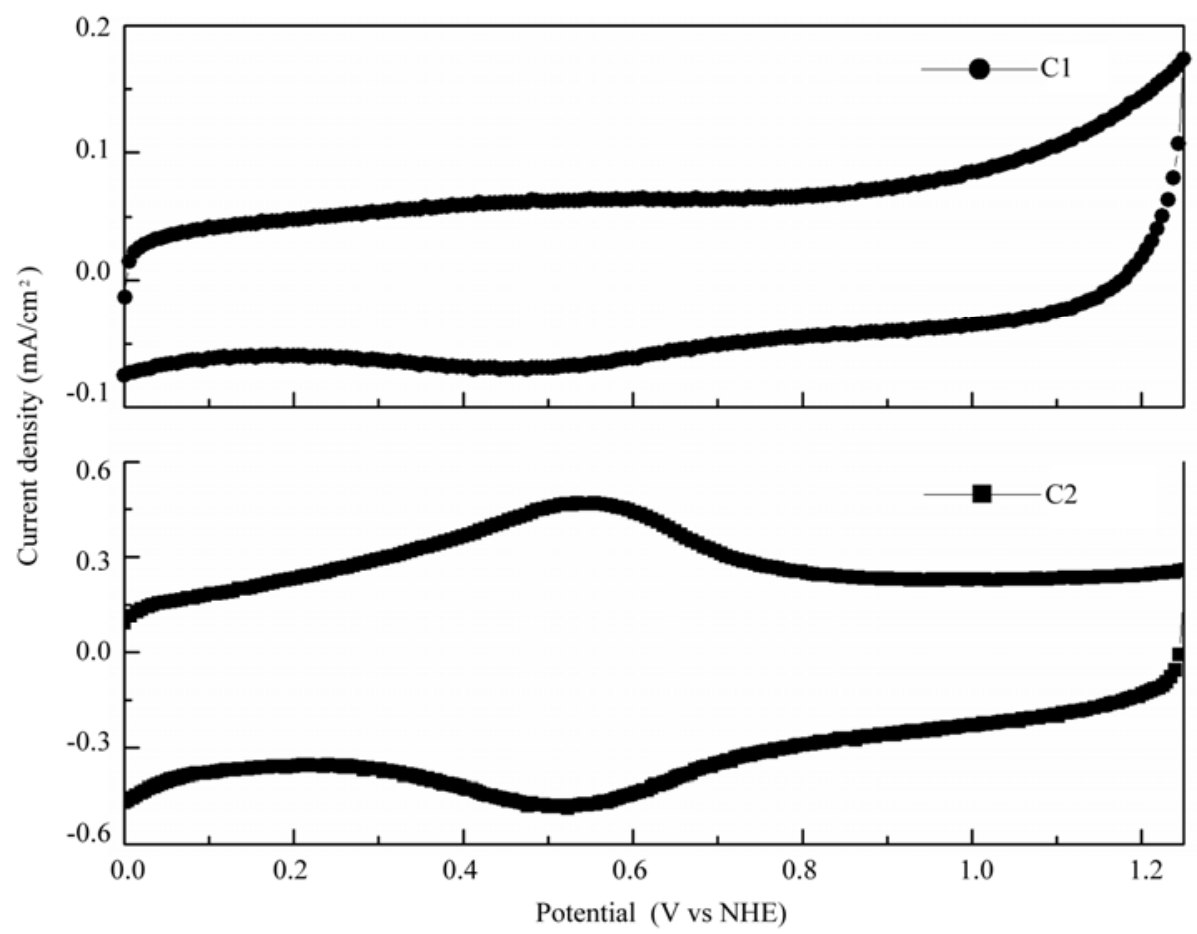

Figure 4. Typical cyclic voltammograms of as-received carbon (C1) and oxidized carbon (C2) in $\mathrm{Ar}_{-}-\mathrm{saturated}^{0.5 \mathrm{M}} \mathrm{H}_{2} \mathrm{SO}_{4}$; Scan rate $-10 \mathrm{mV} / \mathrm{s}$. 


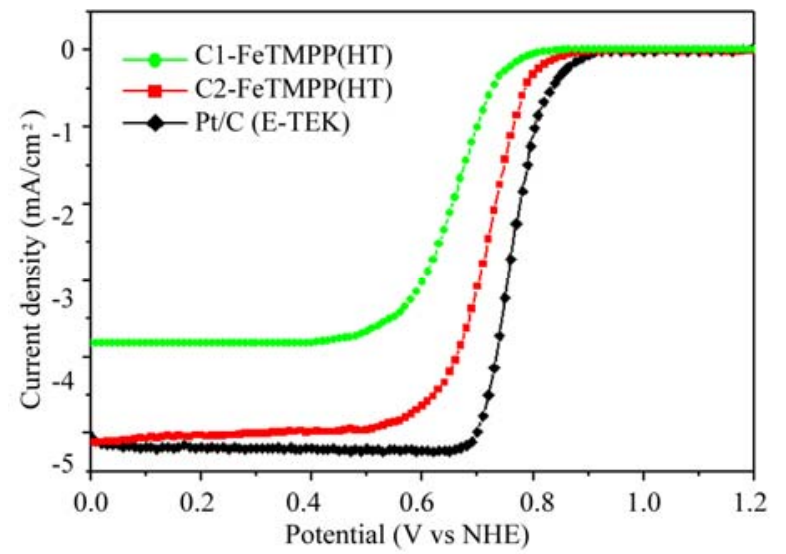

(a)

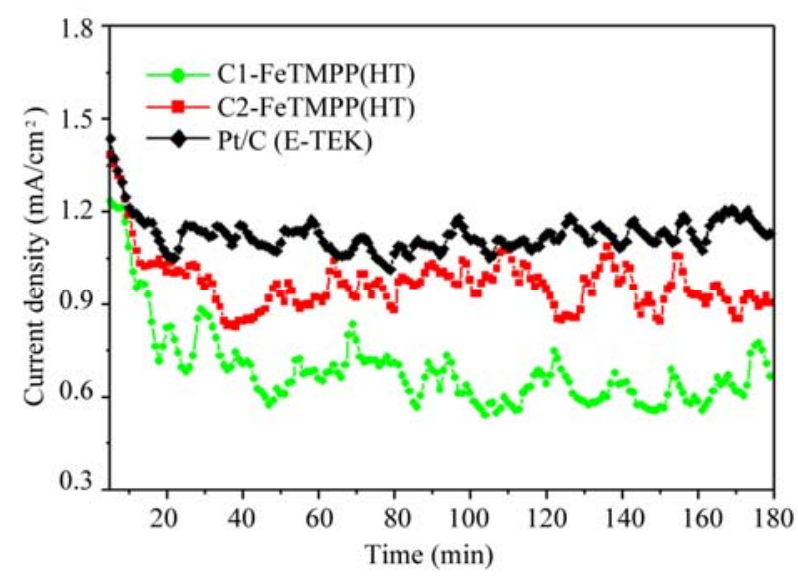

(b)

Figure 5. (a) Linear sweep voltammograms (LSVs) for ORR on C1-FeTMPP(HT), C2-FeTMPP(HT) and Pt/C catalysts in $\mathrm{O}_{2}$ - saturated $0.5 \mathrm{M} \mathrm{H} \mathrm{H}_{2} \mathrm{SO}_{4}$; Scan rate-5 $\mathrm{mV} / \mathrm{s}$ and rotation rate-2500 rpm and (b) Current density-time plots of C1FeTMPP(HT), C2-FeTMPP(HT) and Pt/C catalysts at $0.7 \mathrm{~V}$ vs NHE.

quinone groups on the dispersion of active species, TEM images were recorded for heat-treated FeTMPP adsorbed on $\mathrm{C} 1$ and $\mathrm{C} 2$. The corresponding images were shown in Figure 6(a) and 6(b). Good dispersion of metal cluster species were observed in the case of oxidized carbon compared to as-received carbon. The average size of cluster species in C2-FeTMPP(HT) was $11 \mathrm{~nm}$ compared to 25 $\mathrm{nm}$ for C1-FeTMPP(HT). The small cluster size was due to the increased number of surface functionalities (quinones) on carbon. Good dispersion of metallic clusters in the oxidized carbon might have originated from interfacial bonds with the surface oxygen functionalities. Thus the migration and the coalescence of the active species were considerably lowered by the presence of oxygenated groups which act as anchors for the supported clusters. Therefore by increasing the number of oxygen functionalities on the carbon support by nitric acid treatment, the dispersion of the active species as well as their performance is increased. EDX spectra confirmed the presence of $\mathrm{Fe}, \mathrm{N}, \mathrm{C}$ and a small amount of oxygen in both the catalysts. Since the preparation method involves the pyrolysis of macrocyclic complex at $1073 \mathrm{~K}$, there will be a possibility for the existence of iron oxides and iron carbide. But it has been reported that the ORR activity of iron oxides/hydroxides in acid media is negligible [51]. Also, metallic iron and iron carbide were inactive and not stable in acid media. So the ORR activity is attributed to the $\mathrm{Fe} / \mathrm{N}$ clusters created in the carbon matrix.

\subsection{Single-cell PEMFC Performance with Pt and Fe-based ORR Catalysts}

Single-cell PEMFC performance with C1-FeTMPP(HT), C2-FeTMPP(HT), and $\mathrm{Pt} / \mathrm{C}$ as ORR electrodes was tested at $353 \mathrm{~K}$ and the corresponding polarization
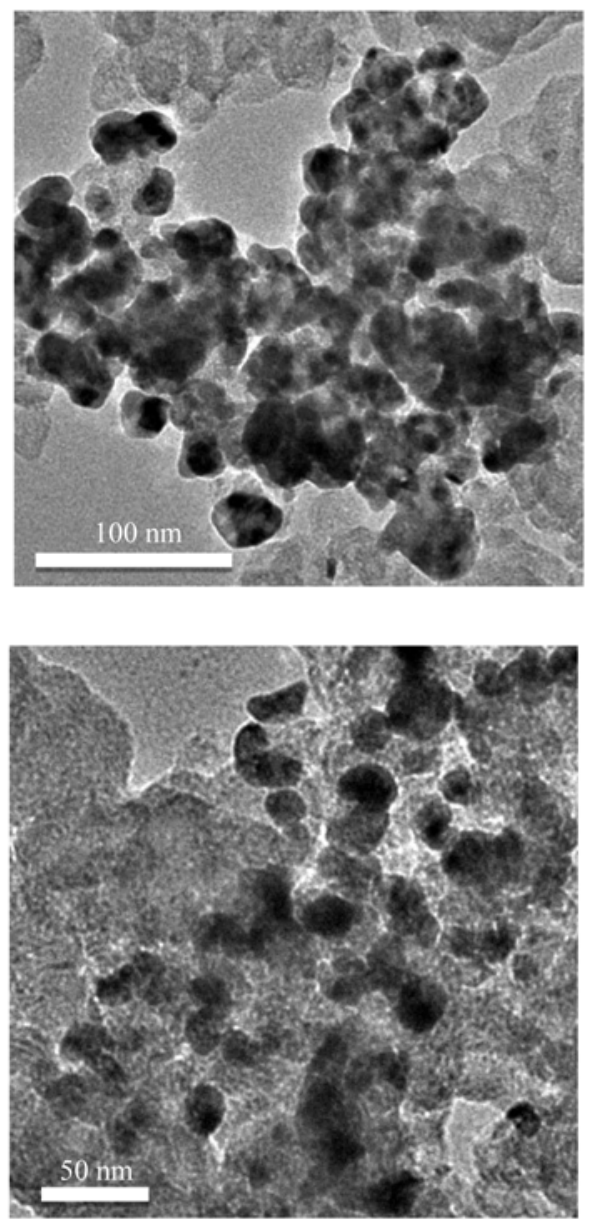

Figure 6. TEM images of (a) C1-FeTMPP(HT) and (b) C2FeTMPP(HT).

curves are shown in Figure 7. The performance observed with high Pt loading $\left(100 \mu \mathrm{g} / \mathrm{cm}^{2}\right)$ at cathode is in good 
agreement with earlier report [51]. In the similar way, fuel cell measurements are performed with $\mathrm{Fe}$-based catalysts and compared with commercial $\mathrm{Pt} / \mathrm{C}$. The open circuit voltage $(\mathrm{OCV})$ values observed with $\mathrm{C} 1$ FeTMPP(HT), C2-FeTMPP(HT), and Pt/C cathodes under identical conditions are $\sim 0.85, \sim 0.89$, and $0.93 \mathrm{~V}$ respectively. The cell potential values measured at different current densities for all the catalysts are provided in Table 1. The cell potential values found with $\mathrm{C} 2-$ FeTMPP(HT) cathode are higher than that of $\mathrm{C} 1-$ FeTMPP(HT) at all the current densities. The high performance is due to the good dispersion and high concentration of $\mathrm{Fe} / \mathrm{N}$ active species at the surface. Jia et al. [37] also observed the enhanced oxygen reduction performance for Pt catalysts supported on $\mathrm{HNO}_{3}$ modified carbon using gas diffusion electrode approach. Sawai and Suzuki [44] also reported the remarkable enhancement in the performance of the air cathodes fabricated with pyrolyzed cobalt hexacyanoferrate dispersed on $\mathrm{HNO}_{3}$ treated carbon support. They proposed that the hydrophilic carboxylic acid groups produced by surface oxidation enhance wetting of the catalyst layer and enhanced proton conductivity in the catalyst layer. At low current density of $50 \mathrm{~mA} / \mathrm{cm}^{2}, \mathrm{C} 2-\mathrm{FeTMPP}(\mathrm{HT})$ exhibited a cell potential of $0.779 \mathrm{~V}$ which is close to be found with $\mathrm{Pt} / \mathrm{C}$ $(0.813 \mathrm{~V})$ with same metal loading. However, the performance of C2-FeTMPP(HT) is inferior to that of $\mathrm{Pt} / \mathrm{C}$ at medium and high current densities. This is due to the low conductivity of C2-FeTMPP(HT). The performance could be improved further by utilizing highly conductive carbon support and optimization in the MEA manufacture and operating conditions. To determine the Tafel slope values, iR-corrected polarization curves are plotted and shown in the inset of Figure 7. Tafel slopes are ob-

Table 1. Estimated metal loading, particle size, and single-cell PEMFC performance of Pt and Fe-based catalysts.

\begin{tabular}{|c|c|c|c|c|c|c|}
\hline \multirow{2}{*}{ Catalyst } & \multirow{2}{*}{$\begin{array}{c}\text { Metal } \\
\text { loading (wt.\%) }\end{array}$} & \multirow{2}{*}{$\begin{array}{l}\text { Particle size } \\
\text { (nm) }\end{array}$} & \multirow{2}{*}{$\begin{array}{l}\text { Cell OCV } \\
\text { (V) }\end{array}$} & \multicolumn{3}{|c|}{ Cell potential at different current densities } \\
\hline & & & & $50 \mathrm{~mA} / \mathrm{cm}^{2}$ & $250 \mathrm{~mA} / \mathrm{cm}^{2}$ & $500 \mathrm{~mA} / \mathrm{cm}^{2}$ \\
\hline C1-FeTMPP(HT) & $\mathrm{Fe}-1.96$ & $25-37$ & 0.85 & 0.742 & 0.616 & 0.495 \\
\hline C2-FeTMPP(HT) & $\mathrm{Fe}-1.97$ & $8-15$ & 0.89 & 0.779 & 0.655 & 0.545 \\
\hline $\begin{array}{l}\mathrm{Pt} / \mathrm{C}(\mathrm{E}-\mathrm{TEK}) \\
\text { (cathode with } 50 \\
\left.\mu \mathrm{g}_{\mathrm{Pt}} / \mathrm{cm}^{2}\right)\end{array}$ & $\mathrm{Pt}-19.8$ & $3.5-3.9$ & 0.93 & 0.813 & 0.711 & 0.634 \\
\hline $\begin{array}{l}\mathrm{Pt} / \mathrm{C}(\mathrm{E}-\mathrm{TEK}) \\
\text { (cathode with } 100 \\
\left.\mu \mathrm{g}_{\mathrm{Pt}} / \mathrm{cm}^{2}\right)\end{array}$ & , & , & 0.94 & 0.835 & 0.746 & 0.671 \\
\hline
\end{tabular}

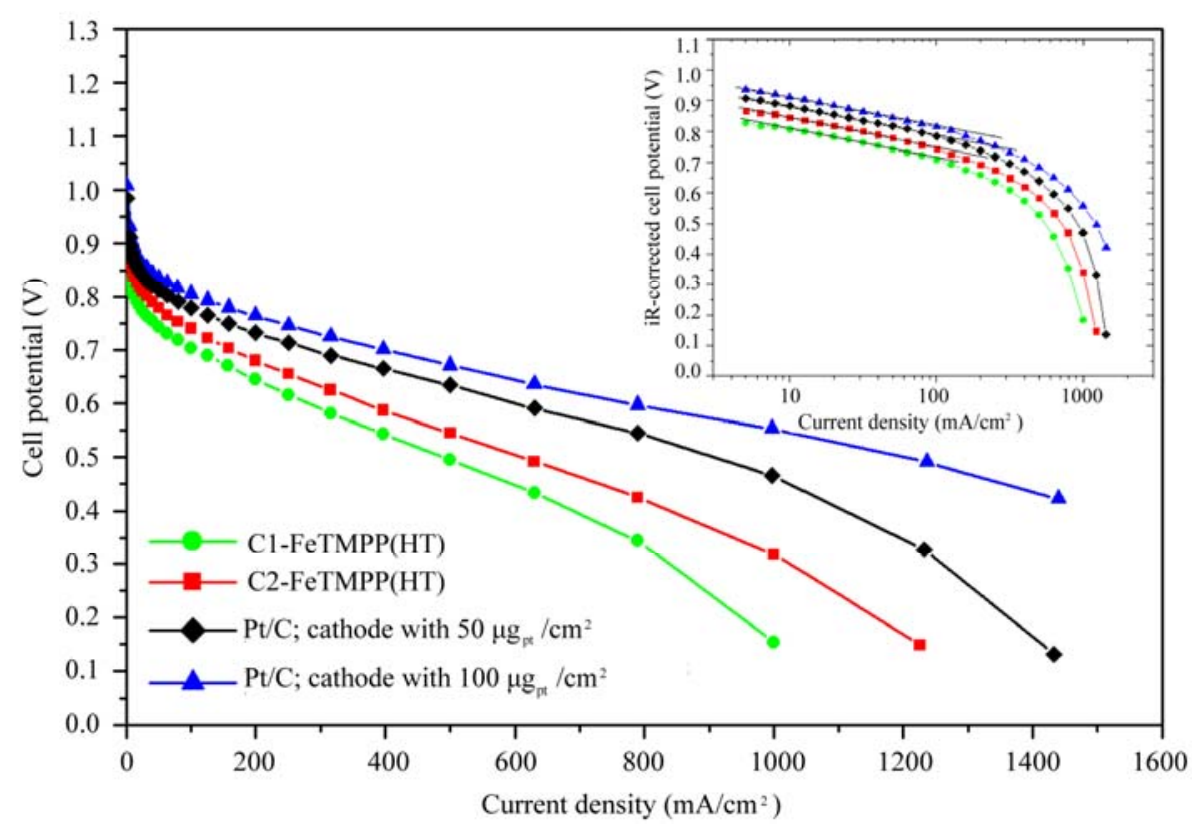

Figure 7. Single-cell PEMFC performance of C1-FeTMPP(HT), C2-FeTMPP(HT), and Pt/C oxygen reduction electrodes at $353 \mathrm{~K}$ Anode: $0.4 \mathrm{mg}_{\mathrm{Pt}} / \mathrm{cm}^{2}$ and cathode: $50 \mu \mathrm{g}_{\mathrm{Fe}} / \mathrm{cm}^{2}$. For comparison, performance of $\mathrm{Pt} / \mathrm{C}$ as cathode with 50 or 100 $\mu \mathrm{g}_{\mathrm{Pt}} / \mathrm{cm}^{2}$ also shown. Inset shows the Tafel plots for the catalysts. 


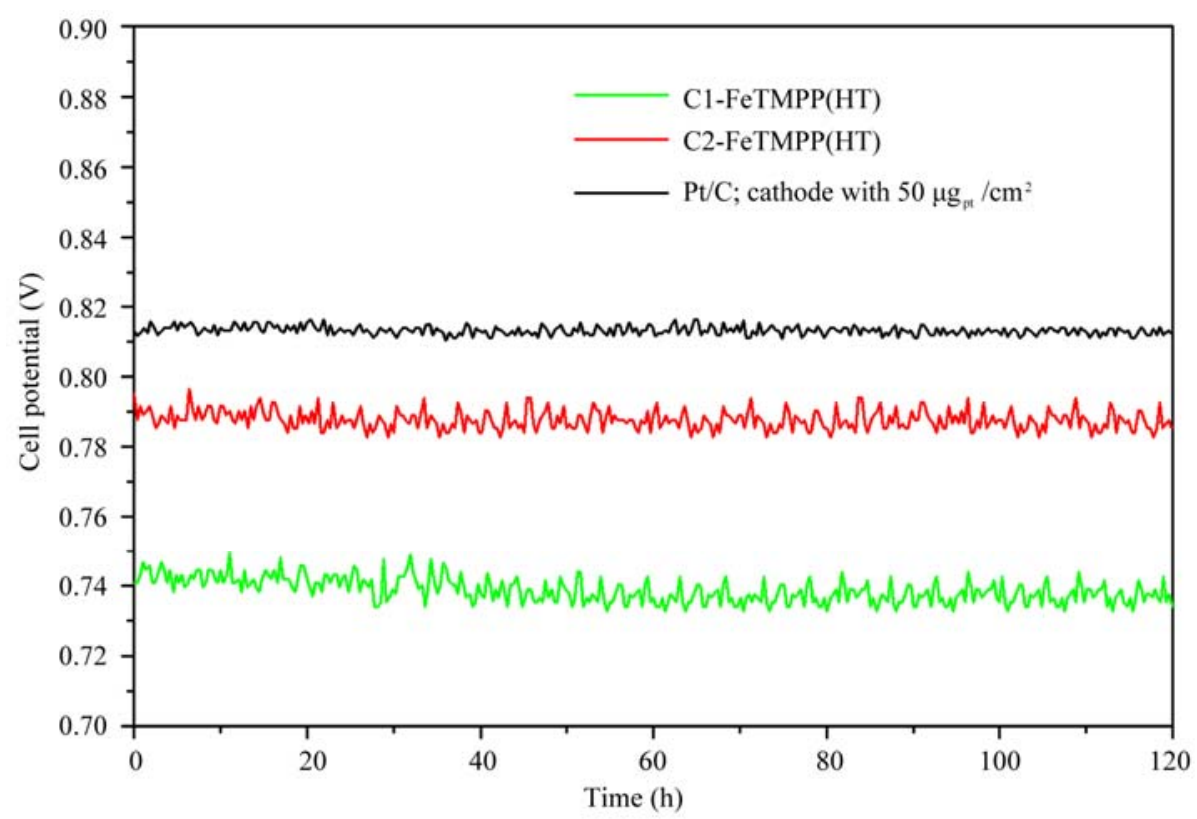

Figure 8. Cell potential-time response of C1-FeTMPP(HT), C2-FeTMPP(HT), and Pt/C oxygen reduction electrodes in single-cell PEMFC at $50 \mathrm{~mA} / \mathrm{cm}^{2}$ for $120 \mathrm{~h}$.

tained from the linear region at low current density. The Tafel slope for C1-FeTMPP(HT), C2-FeTMPP(HT), and $\mathrm{Pt} / \mathrm{C}$ catalysts is $-73,-71$, and $-67 \mathrm{mV} /$ decade respectively. The Tafel slope obtained for $\mathrm{Pt} / \mathrm{C}$ is close to the theoretical Tafel slope at $353 \mathrm{~K}(-70 \mathrm{mV} /$ decade $)$ [52]. The cell potential-time response of the catalysts recorded at $50 \mathrm{~mA} / \mathrm{cm}^{2}$ for $120 \mathrm{~h}$ is shown in Figure 8. Under identical PEMFC conditions, the cell with C2-FeTMPP (HT) and $\mathrm{Pt} / \mathrm{C}$ as cathodes exhibited stable voltage with low polarization losses, whereas the C1-FeTMPP(HT) as cathode exhibited significantly high polarization losses within the period of $120 \mathrm{~h}$. The good stability of C2FeTMPP(HT) compared to C1-FeTMPP(HT) is due to the strong bonding interactions between the active species and oxidized carbon.

\section{Conclusions}

The role exerted by the oxygenated surface groups in the dispersion of $\mathrm{Fe} / \mathrm{N}$ active species responsible for oxygen reduction was studied. The results showed that the introduction of surface oxygen complexes (quinones) on carbon support enhanced the electrocatalytic ORR activity thereby fuel cell performance. The good ORR activity, single-cell PEMFC, and stability performance of carbon supported $\mathrm{Fe} / \mathrm{N}$ clusters advance them as potential ORR electrodes for PEMFC applications.

\section{Acknowledgements}

The authors thank the authorities of Ms. Columbian
Chemicals Company, USA for financial and material support. The authors also wish to acknowledge Department of Science and Technology (DST), India for creating the National Centre for Catalysis Research at IIT Madras.

\section{References}

[1] B. Viswanathan and M. Aulice Scibioh, "Fuel Cells-Principles and Applications," Universities Press (India) Private Limited, New Delhi, 2006.

[2] Ch. Venkateswara Rao and B. Viswanathan, "Monodispersed Platinum Nanoparticle Supported Carbon Electrodes for Hydrogen Oxidation and Oxygen Reduction in Proton Exchange Membrane Fuel Cells," Journal of Physical Chemistry C, Vol. 114, No. 18, 2010, pp. 8661-8667.

[3] T. R. Ralph and M. P. Hogarth, "Catalysis for Low Temperature Fuel Cells. Part I: The Cathode Challenges," Platinum Metals Review, Vol. 46, No. 1, 2002, pp. 3-14.

[4] Ch. Venkateswara Rao and B. Viswanathan, "ORR Activity and Direct Ethanol Fuel Cell Performance of CarbonSupported Pt-M (M = Fe, Co, and Cr) Alloys Prepared by Polyol Reduction Method," Journal of Physical Chemistry C, Vol. 113, 2009, pp. 18907-13.

[5] H. A. Gasteiger, S. S. Kocha, B. Sompalli and F. Wagner, "Activity Benchmarks and Requirements for Pt, Pt-Alloy, and Non-Pt Oxygen Reduction Catalysts for PEMFC," Applied Catalysis B: Environmental, Vol. 56, No. 1-2, 2005, pp. 9-35.

[6] Ch. Venkateswara Rao and B. Viswanathan, " $\mathrm{Ru}_{x} \mathrm{Se}_{y} / \mathrm{C}$ Electrodes for Oxygen Reduction-A Reverse Microemul- 
sion Method of Fabrication of Electrode Material," Journal of Physical Chemistry C, Vol. 111, No. 44, 2007, pp. 16538-16543.

[7] K. Gong, F. Du, Z. Xia, M. Durstock and L. Dai, "Nitrogen-Doped Carbon Nanotube Arrays with High Electrocatalytic Activity for Oxygen Reduction," Science, Vol. 323, No. 5915, 2009, pp. 760-4.

[8] Ch. Venkateswara Rao and B. Viswanathan, "Carbon Supported Pd-Co-Mo Alloy as an Alternative to Pt for Oxygen Reduction in Direct Ethanol Fuel Cells," Electrochimica Acta, Vol. 55, No. 8, 2010, pp. 3002-3007.

[9] M. Lefèvre, E. Proietti, F. Jaouen and J. P. Dodelet, "Ironbased Catalysts with Improved Oxygen Reduction Activity in Polymer Electrolyte Fuel Cells," Science, Vol. 324, No. 5923, 2009, pp. 71-74.

[10] B. Rajesh and P. Zelenay, "A Class of Non-Precious Metal Composite Catalysts for Fuel Cells," Nature, Vol. 443, No. 7107, 2006, pp. 63-6.

[11] R. Jasinski, “A New Fuel Cell Cathode Catalyst," Nature, Vol. 201, 1964, PP. 1212-3.

[12] H. Jahnke, M. Schönborn and G. Zimmermann, "Organic Dyestuffs as Catalysts for Fuel Cells," Topics Current Chemistry, Vol. 61, 1976, pp. 133-181.

[13] J. P. Collman, P. Denisevich, Y. Konai, M. Maraocco, C. Koval and F. C. Anson, "Electrode Catalysis of the Four-Electron Reduction of Oxygen to Water by Dicobalt Face-to- Face Porphyrins," Journal of American Chemistry Society, Vol. 102, No. 19, 1980, pp. 6027-6036.

[14] J. Zagal, M. Paez, A. A. Tanaka, J. R. dos Santos and C. A. Linkous, "Electrocatalytic Activity of Metal Phthalocyanines for Oxygen Reduction," Journal of Electroanalytical Chemistry, Vol. 339, 1992, pp. 13-30.

[15] J. A. R. van Veen, J. F. van Baar and K. J. Kroese, "Effect of Heat treatment on the Performance of Carbon-Supported Transition-metal Chelates in the Electrochemical Reduction of Oxygen," Journal of Chemical Society Faraday Transactions I, Vol. 77, 1981, pp. 2827-43.

[16] D. Scherson, A. A Tanaka, S. L Gupta, D. Tryk, C. Fierro, R. Holze and E. B. Yeager, "Transition Metal Macrocycles Supported on High Area Carbon: Pyrolysis-Mass Spectrometry Studies," Electrochimica Acta, Vol. 31, 1986, pp. 1247-58.

[17] T. Sawaguchi, T. Itlabashi, T. Matsue and I. Uchida, "Electrochemical Reduction of Oxygen by Metalloporphyrin Ion-Complexes with Heat Treatment," Journal of Electroanal Chemistry C, Vol. 279, No. 1-2, 1990, pp. 219-230.

[18] A. Widelov and R. Larson, "ESCA and Electrochemical Studies on Pyrolysed Iron and Cobalt Tetraphenylporphyrins," Electrochimica Acta, Vol. 37, No. 2, 1992, pp. 187-197.

[19] G. Faubert, G. Lalande, R. Cote, D. Guay, J. P. Dodelet, L. T. Weng, P. Bertrand and G. Denes, "Heat-Treated Iron and Cobalt Tetraphenylporphyrins Adsorbed on Carbon Black: Physical Characterization and Catalytic Properties of These Materials for the Reduction of Oxygen in Polymer Electrolyte Fuel Cells," Electrochimica Acta, Vol. 41, No. 10, 1996, pp. 1689-1701.
[20] G. Lalande, G. Faubert, R. Cote, D. Guay, J. P. Dodelet, L. T. Weng and P. Bertrand, "Catalytic Activity and Stability of Heat-Treated Iron Phthalocyanines for the Electroreduction of Oxygen in Polymer Electrolyte Fuel Cells," Journal of Power Sources, Vol. 61, No. 1-2, 1996, pp. 227-237.

[21] S. Lj. Gojkovic, S. Gupta and R. F. Savinell, "Heat-Treated Iron(III) Tetramethoxyphenyl Porphyrin Supported on High-Area Carbon as an Electrocatalyst for Oxygen Reduction. I. Characterization of the Electrocatalyst," Journal of Electrochemical Society, Vol. 145, 1998, pp. 3493-3499.

[22] H. Schulenburg, S. Stankov, V. Schunemann, J. Radnik, I. Dorbandt, S. Fiechter, P. Bogdanoff and H. Tributsch, "Catalysts for the Oxygen Reduction from Heat-Treated Iron (III) Tetramethoxyphenylporphyrin Chloride: Structure and Stability of Active Sites," Journal of Physical Chemistry B, Vol. 107, 2003, pp. 9034-41.

[23] A. Leela Mohana Reddy, N. Rajalakshmi and S. Ramaprabhu, "Cobalt-Polypyrrole-Multiwalled Carbon Nanotube Catalysts for Hydrogen and Alcohol Fuel Cells," Carbon, Vol. 46, No. 1, 2008, pp. 2-11.

[24] H. J. Zhang, X. Yuan, L. Sun, X. Zeng, Q. Jiang, Z. Shao and Z. Ma, "Pyrolyzed $\mathrm{CoN}_{4}$-Chelate as an Electrocatalyst for Oxygen Reduction Reaction in Acid Media," International Journal of Hydrogen Energy, Vol. 35, No. 15, 2010, pp. 2900-2903.

[25] E. B. Easton, R. Yang, A. Bonakdarpour and J. R. Dahn, "Thermal Evolution of the Structure and Activity of Magnetron Sputtered TM-C-N (TM= Fe, Co) Oxygen Reduction Catalysts," Electrochemical and Solid-State Letters, Vol. 10, No. 1, 2007, pp. B6-B9.

[26] R. W. Joyner, J. A. R. van Veen and W. M. H. Sachtler, "Extended X-Ray Absorption Fine Structure (EXAFS) Study of Cobalt-Porphyrin Catalysts Supported on Active Carbon," Journal of Chemical Society Faraday Transactions I, Vol. 78, 1982, pp. 1021-8.

[27] B. van Wingerden, J. A. R. van Veen and C. T. J. Mensch, "An Extended X-Ray Absorption Fine Structure Study of Heat-Treated Cobalt Porphyrin Catalysts Supported on Active Carbon," Journal of Chemical Society Faraday Transactions I, Vol. 84, No. 1, 1988, pp. 65-74.

[28] H. J. Choi, G. Kwag and S. Kim, "Electrochemical and XAFS Investigation of Nitrite Reduction by Heat-treated $\mu$ - oxo derivative of Iron Phthalocyanine Supported on High Area Carbon," Journal of Electroanal Chemistry, Vol. 508, No. 1-2, 2002, pp. 105-114.

[29] M. Lefèvre, P. Bertrand and J. P. Dodelet, "Oxygen Reduction in PEM Fuel Cells: Activity and Active Site Structural Information for Catalysts Obtained by the Pyrolysis at High Temperature of Fe Precursors," Journal of Physical Chemistry B, Vol. 104, 2000, pp. 11238-47.

[30] M. Lefèvre, P. Bertrand and J. P. Dodelet, "Molecular oxygen Reduction in PEM Fuel Cells: Evidence for the Simultaneous Presence of Two Active Sites in Fe-Based Catalysts," Journal of Physical Chemistry B, Vol. 106, No. 34, 2002, pp. 8705-13. 
[31] M. Lefèvre, P. Bertrand and J. P. Dodelet, "Fe-based Catalysts for the Reduction of Oxygen in Polymer Electrolyte Membrane Fuel Cell Conditions: Determination of the Amount of Peroxide Released during Electroreduction and its Influence on the Stability of the Catalysts," Electrochimica Acta, Vol. 48, 2003, pp. 2749-2760.

[32] M. C. Martins Alves, J. P. Dodelet, D. Guay, M. Ladouceur and G. Tourillon, "Origin of the Electrocatalytic Properties for Oxygen Reduction of Some Heat-Treated Polyacrylonitrile and Phthalocyanine Cobalt Compounds Adsorbed on Carbon Black as Probed by Electrochemistry and X-Ray Absorption Spectroscopy," Journal of Physical Chemistry, Vol. 96, No. 26, 1992, pp. 10898-10905.

[33] B. Viswanathan, P. Indraneel and T. K. Varadarajan, "Development of Carbon Materials for Energy and Environmental Applications," Catalysis Surveys Asia, Vol. 13, 2009, pp. 164-183.

[34] A. E. Aksoylu, M. Madalena, A. Freitas, M. F. R. Pereira and J. L. Figueiredo, "The Effects of Different Activated Carbon Supports and Support Modifications on the Properties of Pt/AC Catalysts," Carbon, Vol. 39, 2001, pp. 175-185.

[35] S. Philippe and J. L. Figueiredo, "Carbon Materials for Catalysis," John Wiley \& Sons, Inc. Chichester, 2009.

[36] Ch. Venkateswara Rao, C. R. Cabrera and Y. Ishikawa, "In Search of the Active Site in Nitrogen-Doped Carbon Nanotube Electrodes for the Oxygen Reduction Reaction," Journal of Physical Chemistry Letters, Vol. 1, No. 18, 2010, pp. 2622-2627. doi:10.1021/jz100971v

[37] N. Jia, R. B. Martin, Z. Qi, M. C. Lefebvre and P. G. Pickup, "Modification of Carbon Supported Catalysts to Improve Performance in Gas Diffusion Electrodes," Electrochimica Acta, Vol. 46, No. 18, 2001, pp. 2863-2869.

[38] L. Y. Hsu and H. Teng, "Catalytic NO Reduction with $\mathrm{NH}_{3}$ over Carbons Modified by Acid Oxidation and by Metal Impregnation and Its Kinetic Studies," Applied Catalysis B: Environmental, Vol. 35, No. 2, 2001, pp. 21-30.

[39] J. L. G. de la Fuente, S. Rojas, M. V. Martínez-Huerta, P. Terreros, M. A. Peña and J. L. G. Fierro, "Functionalization of Carbon Support and Its Influence on the ElectroCatalytic Behaviour of $\mathrm{Pt} / \mathrm{C}$ in $\mathrm{H}_{2}$ and $\mathrm{CO}$ Electrooxidation," Carbon, Vol. 44, No. 10, 2006, pp. 1919-29.

[40] M. M. V. M. Souza, N. F. P. Ribeiro and M. Schmal, "Influence of the Support in Selective CO Oxidation on Pt Catalysts for Fuel Cell Applications," International Journal of Hydrogen Energy, Vol. 32, No. 2, 2007, pp. 425-9.

[41] J. R. C. Salgado, R. G. Duarte, L. M. Ilharco, A. M. Botelho do Rego, A. M. Ferraria and M. G. S. Ferreira, "Effect of Functionalized Carbon as Pt Electrocatalyst Support on the Methanol Oxidation Reaction," Applied Catalysisl B: Environmental, 2010, doi:10.1016/j.apcatb.2010.12.031.

[42] Y. Chen, G. Zhang, J. Ma, Y. Zhou, Y. Tang and T. Lu, "Electro-Oxidation of Methanol at the Different Carbon Materials Supported Pt Nano-Particles," International Journal of Hydrogen Energy, Vol. 35, No. 19, 2010, pp. 10109-10117
[43] N. Duteanu, B. Erable, S. M. Senthil Kumar, M. M. Ghangrekar and K. Scott, "Effect of Chemically Modified Vulcan XC-72R on the Performance of Air-Breathing Cathode in a Single-Chamber Microbial Fuel Cell," Bioresource Technology, Vol. 101, No. 14, 2010, pp. 5250-5255.

[44] K. Sawai and N. Suzuki, "Highly Active Non-Platinum Catalyst for Air Cathodes," Journal of Electrochemical Society. Vol. 151, No. 12, 2004, pp. A2132-2137.

[45] H. Wang, R. Cote, G. Faubert, D. Guay and J. P. Dodelet, "Effect of the Pre-Treatment of Carbon black Supports on the Activity of Fe-based Electrocatalysts for the Reduction of Oxygen," Journal of Physical Chemistry B, Vol. 103, No. 12, 1999, pp. 2042-2049.

[46] P. Ehrburger, A. Mongilardi and J. J. Lahaye, "Dispersion of Iron Phthalocyanine on Carbon Surfaces," Journal of Colloid Interface Science, Vol. 91, No. 1, 1983, pp. 151-159.

[47] P. Gouerec, M. Savy and J. Riga, "Oxygen Reduction in Acidic Media Catalyzed by Pyrolyzed Cobalt Macrocycles Dispersed on an Active Carbon: The Importance of the Content of Oxygen Surface Groups on the Evolution of the Chelate Structure during the Heat Treatment," Electrochimica Acta, Vol. 43, No. 7, 1998, pp. 743-753.

[48] P. Nalini Subramanian, P. S. Kumaraguru, H. ColonMercado, H. Kim, N. Branko Popov, T. Black and A. D. Chen, "Studies on Co-Based Catalysts Supported on Modified Carbon Substrates for PEMFC Cathodes," Journal of Power Sources, Vol. 157, No. 1, 2006, pp. 56-63.

[49] A. Smirnova, T. Wender, D. Gobermana, Y. Hu, M. Aindow, W. Rhine and N. M. Sammes, "Modification of Carbon Aerogel Supports for PEMFC Catalysts," International Journal of Hydrogen Energy, Vol. 34, No. 21, 2009, pp. 8992-8997.

[50] S. Barazzouk, M. Lefevre and J. P. Dodelet, "Oxygen Reduction in PEM Fuel Cells: Fe-based Electrocatalysts made with High Surface Area Activated Carbon Supports," Journal of Electrochemical Society, Vol. 156, No. 12, 2009, pp. 1466-1474.

[51] F. Jaouen, S. Marcotte and J. P. Dodelet, "Oxygen Reduction Catalysts for Polymer Electrolyte Fuel Cells from the Pyrolysis of Iron Acetate Adsorbed on Various carbon Supports," Journal of Physical Chemistry B, Vol. 107, No. 6, 2003, pp. 1376-1386.

[52] C. Medard, M. Lefèvre, J. P. Dodelet, F. Jaouen and G. Lindbergh, "Oxygen Reduction by Fe-based Catalysts in PEM Fuel Cell Conditions: Activity and Selectivity of the Catalysts Obtained with two Fe Precursors and Various Carbon Supports," Electrochimica Acta, Vol. 51, No. 16, 2006, pp. 3202-3213.

[53] A. D. Adler, F. R. Longo, F. Kampas and J. Kim, "On the Preparation of Metalloporphyrins," Journal of Inorganic Nuclear Chemistry, Vol. 32, No. 7, 1970, pp. 2443-2445.

[54] R. R. Witherspoon. US Patent 5240893, 1993. 
[55] J. J. Pietron, R. M. Stroud and D. R. Rolison, "Using Three Dimensions in Catalytic Mesoporous Nanoarchitectures," Nano Letters, Vol. 2, No. 5, 2002, pp. 545-549.

[56] I. R. C Belinda, E. J. Contés, M. Lebrón-Colón, M. A. Meador, G. Sánchez-Pomales and C. R. Cabrera, "Combined Electron Microscopy and Spectroscopy Characterization of As-Received, Acid Purified, and Oxidized HiPCO Single-Wall Carbon Nanotubes," Materials Characterization, Vol. 60, No. 12, 2009, pp. 1442-1453.

[57] S. Kundu, Y. Wang, W. Xia and M. Muhler, "Thermal Stability and Reducibility of Oxygen-Containing Functional Groups on Multiwalled Carbon Nanotube Surfaces: A Quantitative High-Resolution XPS and TPD/TPR study," Journal of Physical Chemistry C, Vol. 112, No. 43, 2008, pp. 16869-16878.

[58] R. Haerle, E. Riedo, A. Pasquarello and A. Baldereschi,
" $s p^{2} / s p^{3}$ Hybridization Ratio in Amorphous Carbon from C1s Core-Level Shifts: X-Ray Photoelectron Spectroscopy and First-Principles Calculation," Physical Review B, Vol. 65, No. 4, 2001, p. 045101.

[59] G. Faubert, G. Lalande, R. Cote, D. Guay, J. P. Dodelet, L. T. Weng, P. Bertrand and G. Denes, "Heat-Treated Iron and Cobalt Tetraphenylporphyrins Adsorbed on Carbon Black: Physical Characterization and Catalytic Properties of These Materials for the Reduction of Oxygen in Polymer Electrolyte Fuel Cells," Electrochimica Acta, Vol. 41, No. 10, 1996, pp. 1689-1701.

[60] K. Kinoshita and J. A. S. Bett, "Potentiodynamic Analysis of Surface Oxides on Carbon Blacks," Carbon, Vol. 11, No. 4, 1973, pp. 403-411.

[61] Ch. Venkateswara Rao and B. Viswanathan, "Oxygen Reduction by $\mathrm{FeN}_{4}$ - A DFT Study," Indian Journal of Chemistry A, Vol. 43A, No. 11, 2004, pp. 2333-2335. 